\title{
The Influence of Coconut Fiber on the Compressive and Flexural Strength of Paving Blocks
}

\author{
Rachmat Mudiyono \\ Department of Civil Engineering, \\ Universitas Islam Sultan Agung, \\ Semarang, Indonesia \\ rachmat@unissula.ac.id
}

\author{
S. Sudarno \\ Department of Civil Engineering \\ Universitas Tidar, \\ Indonesia \\ sudarno@untidar.ac.id
}

\begin{abstract}
The aim of this study is to determine the influence of coconut coir fiber on the compressive and flexural strength of paving blocks. The research was carried out using paving blocks with dimensions of $20 \mathrm{~cm} \times 10 \mathrm{~cm} \times 6 \mathrm{~cm}$, mixed with coir fiber by $0 \%, 0.1 \%, 0.2 \%$, and $0.3 \%$ by weight. The results showed that no addition of coconut coir fiber resulted in compressive strength of 24.49Mpa, while the addition of $0.1 \%$ coconut coir fiber resulted in compressive strength of $25.39 \mathrm{Mpa}$ after 7 days. A mixture with no coconut coir fiber resulted in flexural strength of $31.5 \mathrm{Mpa}$ while the addition of $0.1 \%$ coconut coir fiber gave a flexural strength of 33Mpa in the age of 14 days. The conclusion of this study is that the addition of $0.1 \%$ coconut coir fiber in a paving block mixture can increase its compressive and flexural strength.
\end{abstract}

Keywords-coconut coir fiber; paving block; compressive strength; flexural strength

\section{INTRODUCTION}

Coconut fiber use in a reinforced concrete mixture to increase its strength is widely researched. In this study, we used coconut coir fiber for a mixture of paving blocks. Nowadays the technology development in the field of construction has been increased, especially for highway pavement. Paving block pavements start to be widely used for pavement construction on roads [1]. This can be seen from the use of paving blocks which are increasingly used as asphalt replacement because they are easy to install, do not require heavy equipment, can be mass produced, and are easy to maintain and reinstalled. The quality of paving blocks can be measured by their strength in compressive loads and resistance [2]. Paving can withstand small earthquakes, freeze and melt [3]. The contribution of this research is the utilization of coconut fiber as a substitute for steel to paving blocks, making it cheaper.

\section{MATERIALS AND METHODS}

\section{A. Materials}

\section{1) Fiber}

The fiber is a material that has a diameter ranging from 0.00015 to $0.008 \mathrm{~m}$. There are short fibers, continuous fibers and bundle fibers. Fibers have been used to mix concrete for a long time to increase its strength (e.g. asbestos fibers) and for this reason the research of sustainable composite concrete is necessary [4].

\section{2) Effect of Coconut Coir Fiber}

Traditionally coconut fiber is used for household products. Coconut fiber is used in mixes with construction materials to increase their strength [5]. Coconut fiber is divided into two types of colors, namely white from young coconut and brown from old coconut, both with low thermal conductivity [6]. The stress and strain produced by coconut coir fibers have a higher value than other natural fibers [7, 8] Coconut coir fibers can be used in concrete mixtures, because the properties of coconut fiber can bind the concrete material well. Addition of coconut fiber increases the compressive and tensile strength of concrete with the optimal mixture consisting of fibers with $1 \%, 2 \%, 3 \%$ of the weight of cement [9]. Concrete mixed with coconut fiber has compressive strength which always increases with curing age. The maximum compressive strength of a concrete mix with coconut fiber increases for fiber concentrations up to $0.5 \%$ and gradually declines from $0.75 \%$ to $1.0 \%$. The flexural strength of concrete increases in mixtures with coconut coir fiber $0.25 \%, 0.5 \%$ and $1.0 \%$, tested at the age of 28 days[10].

\section{3) Paving Blocks}

In general, there are several types of paving blocks such as rectangle, U-norm, tri hex, hexagonal, etc. Paving blocks are made from a mixture of Portland cement or other hydraulic adhesives, water and aggregates with or without other additives that do not reduce the quality of the concrete. This paper will discuss the effect of the addition of coconut fiber to the flexural strength of rectangular paving blocks [11].

\section{B. Methods}

Coir or coconut fiber is a natural fiber extracted from the husk of the coconut, used in products such as floor mats, doormats, brushes and mattresses. Coir is the fibrous material found between the hard, internal shell and the outer coat of a coconut. Other uses of brown coir are in upholstery padding, sacking and horticulture. White coir, harvested from unripe coconuts, is used for making finer brushes, string, rope and fishing nets. It has the advantage of not sinking, so it can be 
used in long lengths in deep waters [12]. Its chemical composition consists of cellulose, lignin, pyroligneous acid, gasoline, charcoal, tannin and potassium. The primer products from coir are fibers, bristle (smooth and short fibers) and shell fibers [13]. To obtain the water content of coir fiber the steps are cut $\pm 3 \mathrm{~cm}$ of the coir fiber to prevent agglutination. Before conducting tests the coir fibers should be drained first and the old ones should be picked, so the water content will be low [14, $15]$.

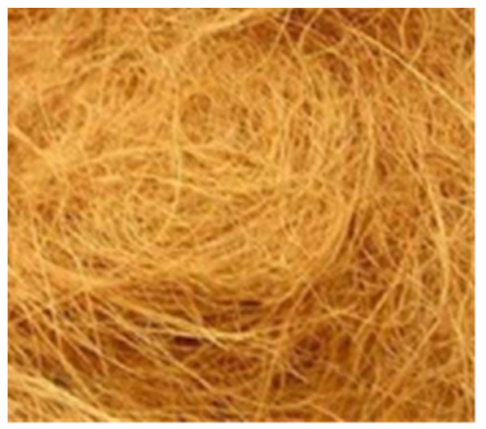

Fig. 1. Coconut coir fiber

TABLE I. COMPOSITION OF COCONUT COIR FIBER [13]

\begin{tabular}{|c|c|c|}
\hline Parameter & Coir fiber & Coir fiber shell \\
\hline Ash & 4.49 & 5.62 \\
\hline SiO & 0.74 & 0.57 \\
\hline Extract & 6.62 & 6.7 \\
\hline Lignin & 37.80 & 43.04 \\
\hline C\&B cellulose & 49.62 & - \\
\hline Alfa cellulose & 33.74 & - \\
\hline Pentosan & 15.63 & 11.51 \\
\hline Dissolve in warm water & 12.51 & 22.16 \\
\hline Dissolve in cold water & 10.29 & 17.22 \\
\hline Dissolve in NaOH 1\% & 34.78 & 45.57 \\
\hline
\end{tabular}

TABLE II. COCONUT COIR FIBER WATER CONTENT

\begin{tabular}{|c|c|c|c|c|c|}
\hline No & $\begin{array}{c}\text { Crucible } \\
\text { weight (g) }\end{array}$ & $\begin{array}{c}\text { Crucible and } \\
\text { aggregate } \\
\text { weight before } \\
\text { ovening (g) }\end{array}$ & $\begin{array}{c}\text { Crucible and } \\
\text { aggregate } \\
\text { weight after } \\
\text { ovening (g) }\end{array}$ & $\begin{array}{c}\text { Water } \\
\text { content (\%) }\end{array}$ & $\begin{array}{c}\text { Average } \\
\text { water content } \\
\text { (\%) }\end{array}$ \\
\hline I & 20 & 70 & 65 & 11 & \multirow{2}{*}{7} \\
\hline II & 45 & 200 & 195 & 3 & \\
\hline
\end{tabular}

\section{1) Sludge Content}

Sludge content test allows us to know the sludge percentage in aggregate. If the sludge content is too much it is not allowed because the material and cement will not combine and will reduce the compressive strength of the paving block [16]. The formula of sludge content is:

$$
W=\frac{V 1}{V 1+V 2}
$$

where $V 1$ is the sand volume and $V 2$ the sludge volume in grams.

TABLE III. SLUDGE CONTENT OF FINE AGGREGATES

\begin{tabular}{|c|c|c|c|c|}
\hline No & $\boldsymbol{V 1}(\mathbf{m l})$ & $\boldsymbol{V} \mathbf{2}(\mathbf{m l})$ & $\boldsymbol{W}(\mathbf{\%})$ & Avg. sludge content (\%) \\
\hline I & 350 & 10 & 2.7 & \multirow{2}{*}{2.8} \\
\hline II & 500 & 15 & 2.9 & \\
\hline
\end{tabular}

\section{2) Procedure of the Making the Paving Blocks}

The mixture compositition paving block used the ratio of 1:2: 2 which is $1 \mathrm{~kg}$ cement, $2 \mathrm{~kg}$ sand, and $2 \mathrm{~kg}$ ash with the addition of $1200 \mathrm{ml}$ of water (not too much water should be added in order to get maximum water-cement ratio). Coir fibers by $0 \%, 0.1 \%, 0.2 \%$, and $0.3 \%$ of cement's weight were added. The mixture compositions were mould. The mould was hit 6 times in order to even up the mixture so there were no air voids. The finished mixture was taken out from the mould into plywood.

\section{3) Curing and Setting Time}

The paving samples were kept away from the elements. During curing time, the paving block was submerged for about one minute every day and covered by gunny sack for 7 and 14 days.
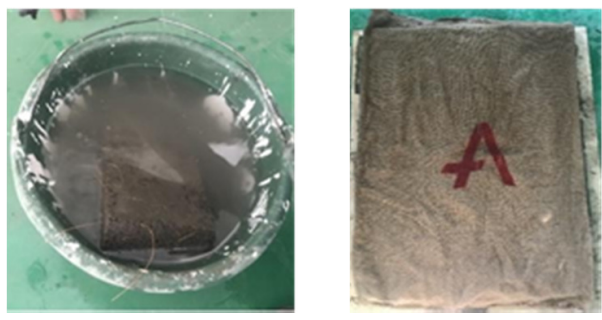

Fig. 2. Paving block curing

III. RESULTS AND DISCUSSION

C. Compressive Strength Test Results

TABLE IV. COCONUT COIR FOBER PAVING BLOCK AT 7 DAYS

\begin{tabular}{|c|c|c|c|c|}
\hline No & Param eter & Weight $\mathbf{( k g )}$ & $\begin{array}{c}\text { Maximum weight } \\
\mathbf{( k N )}\end{array}$ & $\begin{array}{c}\text { Surface area } \\
\mathbf{( m m}^{\mathbf{2}}\end{array}$ \\
\hline $\mathbf{1}$ & CCF 0.0\% & 2.31 & 490 & 19.680 \\
\hline $\mathbf{2}$ & CCF 0.1\% & 2.35 & 510 & 19.680 \\
\hline $\mathbf{3}$ & CCF 0.2\% & 2.36 & 460 & 19.680 \\
\hline $\mathbf{4}$ & CCF 0.3\% & 2.28 & 430 & 19.680 \\
\hline
\end{tabular}

TABLE V. COMPRESSIVE STRENGTH TEST AT 7 DAYS

\begin{tabular}{|c|c|c|c|}
\hline No & Parameter & \multicolumn{2}{|c|}{ Compressive strength } \\
\hline & & $(\mathrm{MPa})$ & $\left(\mathrm{kg} / \mathrm{cm}^{2}\right)$ \\
\hline 1 & CCF $0.0 \%$ & 24.9 & 249 \\
\hline 2 & CCF $0.1 \%$ & 25.9 & 259 \\
\hline 3 & CCF $0.2 \%$ & 23.4 & 234 \\
\hline 4 & CCF $0.3 \%$ & 21.8 & 218 \\
\hline
\end{tabular}

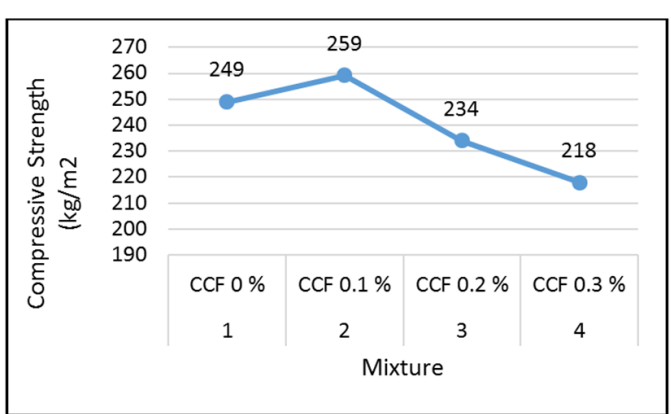

Fig. 3. Coir fiber paving block compressive strength graph at the age of 7 days 
From the result of paving blocks' compressive strength at the age of 7 days (Figure 3) we can see that there is an increase from the addition of $0.1 \%$ coir fiber which was $259 \mathrm{~kg} / \mathrm{cm}^{2}(4 \%$ increase as compared with the normal paving block). This is in accordance with the results of [17]. Figure 4 shows that a mixture with $0.1 \%$ coconut fiber produces a paving block compressive strength of $330 \mathrm{~kg} / \mathrm{cm}^{2}$ which then decreases. This is in accordance with the results reported in [18], namely that concrete mixed with coconut coir fiber will be lighter but in a certain amount will decrease its compressive strength.

TABLE VI. COCONUT COIR FIBER PAVING BLOCK AT 14 DAYS

\begin{tabular}{|c|c|c|c|c|}
\hline No & Parameter & Weight (kg) & Maximum weight $(\mathbf{k N})$ & Surface area $\left(\mathbf{m m}^{\mathbf{2}}\right)$ \\
\hline $\mathbf{1}$ & CCF 0.0\% & 2.41 & 620 & 19.680 \\
\hline $\mathbf{2}$ & CCF 0.1\% & 2.44 & 650 & 19.680 \\
\hline $\mathbf{3}$ & CCF 0.2\% & 2.4 & 620 & 19.680 \\
\hline $\mathbf{4}$ & CCF 0.3\% & 2.38 & 540 & 19.680 \\
\hline
\end{tabular}

TABLE VII. COMPRESSIVE STRENGTH TEST AT 14 DAYS

\begin{tabular}{|c|c|c|c|}
\hline No & Parameter & \multicolumn{2}{|c|}{ Compressive strength } \\
\hline & & $(\mathrm{MPa})$ & $\left(\mathrm{kg} / \mathrm{cm}^{2}\right)$ \\
\hline $\mathbf{1}$ & CCF $0.0 \%$ & 315 & 315 \\
\hline $\mathbf{2}$ & CCF $0.1 \%$ & 33.0 & 330 \\
\hline $\mathbf{3}$ & CCF $0.2 \%$ & 31.5 & 315 \\
\hline $\mathbf{4}$ & CCF $0.3 \%$ & 27.4 & 274 \\
\hline
\end{tabular}

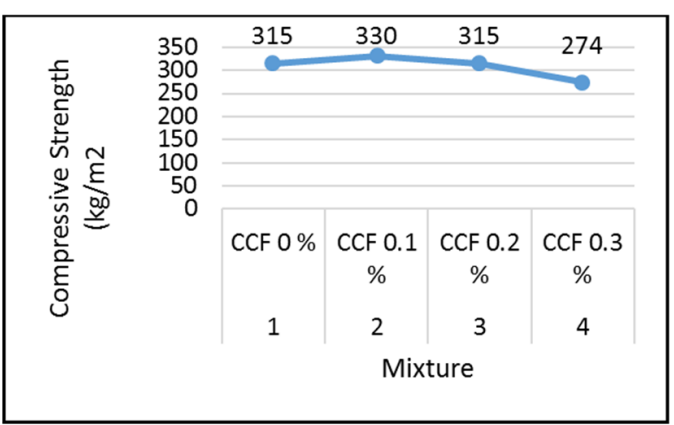

Fig. 4. Coir fiber paving block compressive strength graph at the age of 14 days

\section{Flexural Strength Test Results}

TABLE VIII. FLEXURAL STRENGTH TEST AT 7 DAYS

\begin{tabular}{|c|c|c|c|c|}
\hline No & Parameter & Flexural strength result $(\mathbf{P})$ & \multicolumn{2}{|c|}{ Flexural strength } \\
\hline & & $(\mathrm{kN})$ & $(\mathrm{MPa})$ & $\left(\mathrm{kg} / \mathrm{cm}^{2}\right)$ \\
\hline $\mathbf{1}$ & CCF 0.0\% & 5 & 2.78 & 27.8 \\
\hline $\mathbf{2}$ & CCF 0.1\% & 5 & 2.78 & 27.8 \\
\hline $\mathbf{3}$ & CCF 0.2\% & 7 & 3.89 & 38.9 \\
\hline $\mathbf{4}$ & CCF 0.3\% & 6 & 3.33 & 33.3 \\
\hline
\end{tabular}

TABLE IX. FLEXURAL STRENGTH TEST AT 14DAYS

\begin{tabular}{|c|c|c|c|c|}
\hline No & Parameter & Flexural Strength Result (P) & \multicolumn{2}{|c|}{ Flexural Strength } \\
\hline & & $(\mathrm{KN})$ & $(\mathrm{MPa})$ & $\left(\mathrm{kg} / \mathrm{cm}^{2}\right)$ \\
\hline $\mathbf{1}$ & CCF $0.0 \%$ & 6 & 3.33 & 33.3 \\
\hline $\mathbf{2}$ & CCF $0.1 \%$ & 6 & 3.33 & 33.3 \\
\hline $\mathbf{3}$ & CCF $0.2 \%$ & 7 & 3.89 & 38.9 \\
\hline $\mathbf{4}$ & CCF $0.3 \%$ & 8 & 4.44 & 44.4 \\
\hline
\end{tabular}

Figures 5-6 show that paving blocks mixed with $0.2 \%$ coconut coir fibers produce flexural strength that at first rises and then decreases with increasing amount of coconut fibers [19-21].

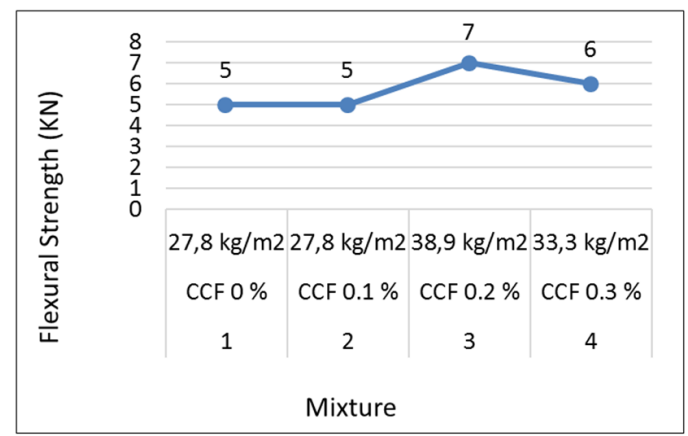

Fig. 5. Coir fiber paving block flexural strength graph at the age of 7 days

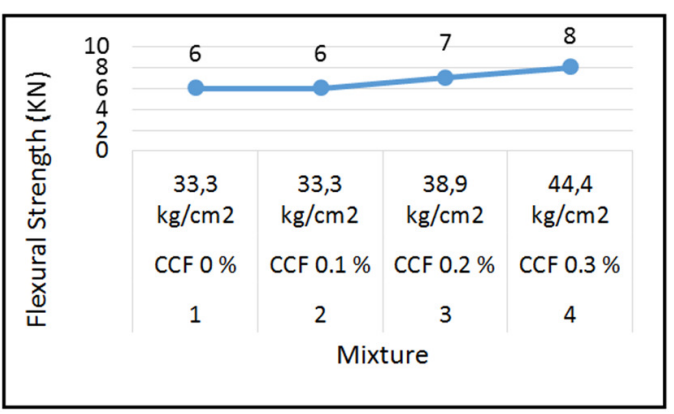

Fig. 6. Coir fiber paving block flexural strength graph at the age of 14 days

\section{CONCLUSION}

The results showed that with no coconut coir fiber addition, the paving blocks resulted having compressive strength of 24.49Mpa. The addition of $0.1 \%$ coconut coir fiber resulted in compressive strength of $25.39 \mathrm{Mpa}$ in the age of 7 days. For a mixture of $0 \%$ coconut coir fiber the result was a flexural strength of $31.5 \mathrm{Mpa}$, while the addition of $0.1 \%$ coconut coir fiber gave a flexural strength of $33 \mathrm{Mpa}$ in 14 days. The conclusion of this study is that the addition of $0.1 \%$ coconut coir fiber can make a paving block mixture increase its compressive and flexural strength.

\section{REFERENCES}

[1] M. Qomaruddin, S. Sudarno, "Influence of bottom-ash mixed with gypsum as concrete bricks for wall construction material", Journal of Applied Environmental and Biological Sciences, Vol. 8, No. 4, pp. 109114,2018

[2] I. P. Hastuty, I. S. S. Nursyamsi, "Comparison of Compressive Strength of Pavingblock with a Mixture of Sinabung Ash and Pavingblock with a Mixture of Lime", IOP Conference Series: Materials Science and Engineering, Vol. 309, Article ID 012011, 2018

[3] S. I. Zia, "Use of coconut fiber concrete", International Research Journal of Engineering and Technology, Vol. 2, No. 6, pp. 235-237, 2015

[4] A. Abdullah, S. B. Jamaludin, M. M. Noor, K. Hussin, "Composite cement reinforced coconut fiber: Physical and mechanical properties and fracture behaviour", Australian Journal of Basic and Applied Sciences, Vol. 5, No. 7, pp. 1228-1240, 2011

[5] A. N. Ede, A. O. Ige, "Optimal polypropylene fiber content for improved compressive and flexural strength of concrete", IOSR Journal of Mechanical and Civil Engineering, Vol. 11, No. 3, pp. 129-135, 2014 
[6] N. M. S. Hasan, H. R. Sobuz, M. S. Sayed, M. S. Islam, "The use of coconut fibre in the production of structural lightweight concrete", Journal of Applied Sciences, Vol. 12, No. 9, pp. 831-839, 2012

[7] M. A. Aziz, P. Paramasivam, S. L. Lee, "Concrete reinforced with natural fibres", in: Concrete Technology and Design Vol. 2: New Reinforced Concretes, pp. 107-140, Surrey University Press, 1984

[8] C. Asasutjarit, J. Hirrunlabh, J. Khedari, M. Paguenet, D. Quenard, "Coconut Coir Cement Board", 10th International Conference on the Durability of Building Materials and Components, Lyon, France, April 17-20, 2005

[9] P. Paramasivam, G. K. Nathan, N. C. D. Gupta, "Coconut fibre reinforced corrugated slabs", International Journal Cement Composites Lightweight Concrete, Vol. 6, No. 1, pp. 19-27, 1984

[10] M. Brahmakumar, C. Pavithran, R. M. Pillai, "Coconut fibre reinforced polyethylene composites: Effect of natural waxy surface layer of the fibre on fibre/matrix interfacial bonding and strength of composites", Composites Science and Technology, Vol. 65, No. 3-4, pp. 563-569, 2005

[11] A. H. Chkheiwer, "Improvement of concrete paving blocks properties by mineral additions", Journal of Babylon University/Engineering Sciences, Vol. 25, No. 1, pp. 157-164, 2017

[12] O. Owolabi, T. Czvikovszky, I. Kovacs, "Coconut fibre reinforced thermosetting plastics", Journal of Applied Polymer Science, Vol. 30, No. 5, pp. 1827-1836, 1985

[13] D. Verma, P. C. Gope, "The use of coir/coconut fibers as reinforcements in composites", in Biofiber Reinforcements in Composite Materials, Woodhead Publishing, pp. 285-319, 2014

[14] E. A. Olanipekun, K. O. Olusola, O. Ata, "A comparative study of concrete properties using coconut shell and palm kernel shell as coarse aggregates", Building and Environment, Vol. 41, No. 3, pp. 297-301, 2006

[15] V. Anggraini, A. Asadi, B. B. K. Huat, H. Nahazanan, "Effects of coir fibers on tensile and compressive strength of lime treated soft soil", Measurement, Vol. 59, pp. 372-381, 2015

[16] A. Y. Adeyemi, "An investigation into the suitability of coconut shells as aggregates in concrete production", Journal of Environment Design and Management, Vol. 1, pp. 17-26, 1998

[17] K. G. Satyanarayana, C. K. S. Pillai, K. Sukumaran, S. G. K. Pillai, P. K. Rohatgi, K. Vijayan, "Structure property studies of fibres from various parts of the coconut tree", Journal of Materials Science, Vol. 17, No. 8, pp. 2453-2462, 1982

[18] K. Gunasekaran, P. S. Kumar, "Lightweight Concrete Using Coconut Shells as Aggregate", International Conference on Advances in Concrete and Construction, Hyderabad, India, February 7-9, 2008

[19] A. N. Ede, J. O. Agbede, "Use of coconut husk fiber for improved compressive and flexural strength of con-crete", International Journal of Scientific and Engineering Research, Vol. 6, No. 2, pp. 968-974, 2015

[20] S. S. Munawar, K. Umemura, S. Kawai, "Characterization of the morphological, physical, and mechanical properties of seven nonwood plant fibre bundles", Journal of Wood Science, Vol. 53, No. 2, pp. 108113, 2007

[21] R. Shikha, A. K. Saxena, A. K. Jha, "Evaluation of compressive strength of concrete using coconut coir fibre", International Journal for Research in Applied Science \& Engineering Technology, Vol. 3, No. 9, pp. 313317,2015

AUTHORS PROFILE

Rachmat Mudiyono graduated and obtained a $\mathrm{PhD}$ in Engineering from the Universiti Teknologi Malaysia in 2001. He is the Dean of the Faculty of Engineering, Universitas Islam Sultan Agung Semarang, Indonesia. His main research interest is pavement structures using paving blocks.

S. Sudarno finished his $\mathrm{PhD}$ in Environmental Engineering from the Universitas Diponegoro Semarang, Indonesia in 2015. His main research interest is pavements using environmentally friendly materials. He works as a lecturer at the Department of Civil Engineering, Universtas Tidar, Indonesia. 